\title{
PENGARUH CEKAMAN KEKERINGAN TERHADAP PERILAKU FISIOLOGIS DAN PERTUMBUHAN BIBIT BLACK LOCUST (Robinia pseudoacacia)
}

\section{NOVITA ANGGRAINI*, ENY FARIDAH, \& SAPTO INDRIOKO}

\author{
Bagian Silvikultur, Fakultas Kehutanan, Universitas Gadjah Mada \\ Jl. Agro No.1 Bulaksumur, Sleman 55281 \\ *Email: novita.novi.anggraini@gmail.com
}

\begin{abstract}
Black locust (Robinia pseudoacacia) is a native species from North America and it has spread to Europe and Asia. Black locust is also one species used for land rehabilitation in semiarid and arid areas. However, adaptability of black locust on their distribution area is quite disturbing due to its invasive potential that tends to suppress the growth of native plants. The purpose of this study is to examine the effect of drought stress through watering volume and watering intervals treatments on physiological behavior and growth of black locust seedlings, and to analyze the level of black locust on drought tolerance through water use efficiency (WUE) character and chlorophyll content. The watering volumes are 30-40\% of field capacity representing drought conditions and 70-80\% of field capacity representing good water conditions, while the watering intervals are 1, 3 and 7 days. Trend analysis is used to analyze the data. The results indicate that the lower watering volume (30-40\%) and the longer the watering interval (for 7 days), the lower the photosynthesis and transpiration rate, stomatal conductance and growth (height, diameter, shoot dry weight and root) of plants, but the higher the WUE and chlorophyll content. Increasing WUE and chlorophyll content are two indicators indicating that black locust is able to adapt (tolerant) to drought stress situations. Therefore, the use of black locust for dry land reclamation requires special attention and careful strategy to avoid its invasive impact in the future.
\end{abstract}

Keywords: black locust, drought, invasive species, water use efficiency, chlorophyll content.

\section{INTISARI}

Black locust (Robinia pseudoacacia) merupakan tanaman asli Amerika Utara dan telah tersebar ke Eropa dan Asia serta menjadi salah satu spesies yang digunakan untuk rehabilitasi lahan semiarid dan arid. Walau demikian, kemampuan adaptasi black locust pada daerah persebarannya cukup meresahkan disebabkan jenis ini memiliki potensi invasif yang cenderung menekan pertumbuhan tanaman asli setempat. Tujuan penelitian ini adalah untuk mempelajari pengaruh cekaman kekeringan berupa volume penyiraman dan interval penyiraman terhadap perilaku fisiologis dan pertumbuhan bibit black locust, serta untuk menganalisis tingkat toleransi black locust terhadap kekeringan melalui karakter efisiensi penggunaan air (WUE) dan kandungan klorofil. Perlakuan volume penyiraman berupa kapasitas lapang 30-40\% mewakili kondisi kekeringan dan kapasitas lapang 70-80\% mewakili kondisi air yang memadai, sementara periode interval penyiraman adalah 1 hari, 3 hari dan 7 hari. Metode analisis yang digunakan ialah analisis tren. Hasil yang diperoleh pada penelitian ini adalah semakin rendah volume penyiraman (KL 30-40\%) dan semakin lama interval penyiraman (ke 7 hari) maka fotosintesis, transpirasi, konduktansi stomata, serta pertumbuhan (tinggi, diameter, berat kering tajuk dan akar) akan semakin rendah, sementara untuk WUE dan kandungan klorofil semakin tinggi. Peningkatan WUE dan kandungan klorofil merupakan dua indikator bahwa black locust mampu beradaptasi (toleran) pada kondisi cekaman kekeringan. Dengan begitu, dapat disimpulkan bahwa 
penggunaan black locust dalam upaya reklamasi lahan kering perlu didahului studi khusus dan pertimbangan yang matang agar tidak membawa dampak invasif pada kehidupan mendatang.

Kata kunci: black locust, cekaman kekeringan, jenis invasif, water use efficiency, kandungan klorofil.

\section{PENDAHULUAN}

Kekeringan merupakan faktor abiotik penting yang berhubungan dengan rendahnya ketersediaan air tanah, terhambatnya pertumbuhan tanaman dan restorasi ekologi pada daerah arid maupun semi arid (Liu et al., 2013). Sementara itu, tanaman di luar daerah arid maupun semi arid juga sering mengalami defisit air pada siklus hidupnya (Chaves et al., 2002) yang penyebabnya termasuk perubahan signifikan intensitas dan frekuensi suhu bumi serta pola curah hujan, peningkatan suhu atau penurunan kelembaban yang cepat yang mengakibatkan kondisi defisit air yang parah pada tanaman (IPCC dalam Micco dan Aronne, 2012). Kondisi seperti ini memicu stres pada tanaman, yang berpotensi menyebabkan tekanan biologis (baik proses fisiologis maupun aktivitas fungsional) pada organisme hidup yang disebabkan faktor lingkungan (Levitt dalam Zlatev dan Lidon, 2012). Respon pertama tanaman dalam menanggapi kondisi defisit air yang parah ialah dengan cara menutup stomata (Mahajan dan Tuteja, 2005). Penurunan tekanan turgor yang bersamaan dengan meningkatnya asam absisat bebas pada daun menyebabkan penyempitan stomata (Nilsen dan Orcutt, 1996). Penutupan dan/atau penyempitan stomata menghambat proses fotosintesis, hal ini menyangkut transportasi air dalam tubuh tanaman dan menurunnya aliran karbondioksida pada daun (Nilsen dan Orcutt, 1996; Zlatev dan Lidon, 2012). Penurunan konsentrasi karbondioksida pada daun mempengaruhi mobilisasi pati dan berpotensi meningkatkan respirasi (Nilsen dan Orcutt, 1996).
Tanaman akan mengurangi penggunaan cadangan karbohidrat untuk mempertahankan proses metabolismenya, dan hal ini memicu kekurangan karbon sehingga tanaman akan mengalami penurunan pertumbuhan dan semakin lama tanaman akan mengalami kematian (Mc Dowell et al., dalam Liu et al., 2012).

Robinia pseudoacacia (black locust) merupakan salah satu jenis tanaman yang resisten terhadap cekaman kekeringan (Gomez dan Wagner, 2001; Rëdei et al., 2012), sehingga sering digunakan pada reklamasi lahan daerah arid dan semi arid serta untuk mengatasi kekeringan yang disebabkan kondisi iklim saat ini. Black locust digunakan pada proyek reklamasi hutan di daerah arid Iran (Moshki dan Lamersdorf, 2010); untuk restorasi pada lahan marginal yang ketersediaan air dan $\mathrm{N}$ tanahnya rendah di Loess Plateau dan daerah arid lainnya di Cina (Liu et al., 2012), serta digunakan sebagai pupuk alami bagi pohon pinus di hutan pantai Jepang (Jung et al., 2009). Black locust yang awalnya digunakan untuk tujuan reklamasi dan produksi di beberapa negara persebarannya, saat ini telah berpotensi menjadi invasif. Di Jepang, keberadaan black locust terindikasi menghambat regenerasi anakan Pinus thunbergii yang merupakan jenis alami hutan pantai Jepang (Taniguchi et al., 2007). Di Korea, black locust telah menghabiskan biaya cukup besar untuk pembasmiannya (Lee et al., 2004). Black locust juga dikategorikan sebagai jenis invasif di beberapa negara Eropa termasuk Polandia (Rahmonov, 2009), Swiss dan Italia Utara (Sabo, 2000), bahkan termasuk ke dalam kategori 100 
tanaman berkayu invasif menurut Cronk dan Fuller dalam Masaka dan Yamada (2009).

Penelitian ini dimaksudkan untuk mempelajari adaptasi black locust terhadap cekaman kekeringan dalam upaya mengontrol perkembangan keinvasifannya pada daerah arid, semi arid maupun kekeringan karena faktor perubahan iklim global. Oleh karenanya, penelitian ini dilakukan untuk mempelajari pengaruh cekaman kekeringan berupa volume dan interval penyiraman terhadap perilaku fisiologis dan pertumbuhan bibit black locust, serta untuk menganalisis tingkat toleransinya terhadap kekeringan melalui karakter efisiensi penggunaan air (WUE) dan kandungan klorofil. Penelitian ini diharapkan mampu memberikan informasi terkait mekanisme adaptasi black locust terhadap cekaman kekeringan agar dapat digunakan sebagai bahan informasi dan strategi dalam mengelola dan mengontrol perkembangan black locust sebagai salah satu jenis invasif pada daerah arid dan semi arid.

\section{BAHAN DAN METODE}

\section{Lokasi dan Waktu Penelitian}

Penelitian ini dilakukan di Green House dan Laboratorium Fisiologi Tanaman Sayur dan Buah, Fakultas Pertanian, Universitas Yamagata, Jepang selama 7 bulan dimulai dari bulan Februari (akhir musim dingin) hingga Agustus (musim panas) 2014. Rentang waktu penelitian dihitung mulai dari perkecambahan benih hingga pemanenan biomassa dan perhitungan klorofil. Perkecambahan di growth chamber dimulai pada Februari hingga awal Maret dan selanjutnya dipindahkan ke rumah kaca. Pemberian perlakuan dimulai pada bulan Juli 2014 hingga pertengahan Agustus 2014 (6 pekan), pada saat musim panas dengan suhu rata-rata $19-35{ }^{\circ} \mathrm{C}$ dengan rentang waktu siang 04.00-20.00 (16 jam) dan malam 20.00-04.00 (8 jam).

\section{Alat dan Bahan Penelitian}

Alat yang digunakan dalam penelitian ini meliputi alat perkecambahan sampel (cawan petri, kertas saring, kapas, growth chamber, polybag, dan kertas label), alat di rumah kaca (timbangan manual ukuran $10 \mathrm{~kg}$, meteran, kaliper, LI-COR 6400XT, dan leaf porometer) serta alat di laboratorium (plastik, oven, bor ukuran $6 \mathrm{~mm}$, timbangan analitik, mortar, tabung reaksi, freezer, mixer, sentrifugal machine, botol plastik, labu ukur, corong kecil, dan spektrofotometer UV-1200). Bahan penelitian yang digunakan meliputi benih tanaman black locust, larutan hidrogen peroksida $\left(\mathrm{H}_{2} \mathrm{O}_{2}\right) 3 \%$, tanah kompos (4 $\mathrm{kg} /$ pot$)$, pupuk NPK $(250 \mathrm{~g} / 10 \mathrm{~kg})$ serta aseton $80 \%$.

\section{Prosedur Penelitian}

\section{Pembuatan Sampel Tanaman}

Benih yang diperoleh dari Laboratorium Ekologi Hutan (Ilmu Perbenihan), disterilisasi dengan cara direndam pada larutan $\mathrm{H}_{2} \mathrm{O}_{2} 3 \%$ selama 30 menit dan selanjutnya didistilasi dengan air selama 24 jam. Kemudian, benih diletakkan ke dalam cawan petri yang telah diberi kertas saring dan kapas. Perkecambahan terjadi kurang lebih tiga hari setelah diletakkan di dalam growth chamber dengan perbandingan waktu 12 jam terang dan 12 jam gelap, serta kelembaban rata-rata sekitar $60 \%$. Setelah radikula mencapai panjang $20 \mathrm{~mm}$, bibit dipindahkan ke pot plastik yang telah diisi tanah kompos, dengan tetap ditumbuhkan dalam growth chamber. Setelah dua minggu, bibit ditransplantasi ke polybag ukuran $15 \mathrm{~cm}$ dan dipindahkan ke rumah kaca, disiram secara teratur, dibersihkan dari gulma sampai sebelum penelitian dilakukan. Setelah bibit berumur 4 bulan, keseluruhan bibit ditransplantasi ke dalam pot ukuran $30 \mathrm{~cm}$ yang telah disi dengan tanah dan diberi pupuk NPK untuk kemudian mendapat perlakuan. 


\section{Prosedur Penerapan Perlakuan}

Perlakuan yang diujikan pada bibit black locust berumur 4 bulan adalah volume dan interval penyiraman. Volume penyiraman terdiri dari 2 tingkat yakni $70 \%$ dari kapasitas lapangan atau cukup air dan $30 \%$ dari kapasitas lapang atau disebut kekeringan (Xu et al., 2009; Li et al., 2008; Liu et al., 2013; Yang et al., 2014). Sementara itu, perlakuan interval penyiraman terdiri dari 3 tingkat yakni penyiraman 1 hari sekali, 3 hari sekali, dan 7 hari sekali selama 6 minggu (Mazher et al., 2007; Mona dan Amin, 2013).

Volume penyiraman pada setiap pot diatur dengan menggunakan metode gravimetric probe (Wang et al., 2009). Pada metode ini, setiap pot (termasuk benih, tanah dan berat pot) ditimbang setiap hari untuk interval penyiraman satu hari, ditimbang setiap tiga hari untuk interval penyiraman 3 hari dan ditimbang setiap minggu untuk interval penyiraman 7 hari, dalam rangka menjaga kandungan air. Seluruh pot diletakkan pada tempat yang aman dari gangguan air hujan. Perlakuan dimulai pada tanggal 3 Juli 2014.

\section{Pengamatan dan Pengukuran}

\section{Pengukuran Pertumbuhan}

Tinggi dan diameter bibit diukur sejak perlakuan diberikan dan dilakukan setiap lima hari sekali hingga masa panen (6 minggu) dengan menggunakan meteran dan kaliper. Pengukuran diameter dan tinggi dilakukan pada lokasi yang telah diberi tanda $(1 \mathrm{~cm}$ dari permukaan tanah). Berat kering dari daun, batang, dan akar diukur untuk menghitung biomassa dilakukan di akhir (masa panen). Daun, batang, dan akar bibit dicuci secara terpisah dengan air mengalir dan selanjutnya dikering oven dengan suhu $80{ }^{\circ} \mathrm{C}$ selama 48 jam (Gao, 2000).

\section{Pengukuran Kandungan Klorofil}

Pengukuran dilakukan di Laboratorium Fisiologi Tanaman, Fakultas Pertanian, Universitas Yamagata, Jepang. Pengukuran dilakukan pada akhir penelitian (bersamaan dengan pemanenan biomasa tanaman). Kandungan klorofil (klorofil a dan klorofil b) dihitung dengan menggunakan metode Arnon (Nishizawa, 2013). Berdasarkan Yang et al. (2014), sampel daun segar (daun kelima dari bagian atas bibit) dibersihkan, lalu sampel dibentuk menggunakan bor ukuran $6 \mathrm{~mm}$. Sampel segar ditimbang untuk selanjutnya digiling dengan menggunakan mortar (bisa juga menggunakan larutan nitrogen untuk mempermudah penggilingan). Setelah halus, sampel diberi larutan aseton $80 \%$, kemudian diletakkan di dalam tabung reaksi dan disimpan sementara dalam freezer untuk mencegah degradasi klorofil. Setelah selesai digiling, seluruh sampel disentrifugasi untuk memisahkan ampas dengan larutan. Ampas tetap dibiarkan di dalam tabung reaksi sementara larutan dipindahkan ke dalam botol plastik dan disimpan di dalam freezer. Pada tabung reaksi yang berisi ampas, ditambahkan larutan aseton $80 \%$ sebanyak $3 \mathrm{ml}$, dicampur menggunakan mixer dan disentrifugasi kembali. Larutan yang telah terpisah dari ampas dimasukkan ke dalam botol plastik. Selanjutnya, seluruh larutan yang dihasilkan (yang berada pada botol plastik), dituangkan ke dalam labu ukur dan ditambahkan aseton $80 \%$ untuk mencapai larutan sebanyak $25 \mathrm{ml}$. Absorbansi larutan diukur dengan menggunakan spektrofotometer UV-1200 dengan panjang gelombang $645 \mathrm{~nm}$ dan $663 \mathrm{~nm}$. Metode ini dilakukan pada setiap sampel perlakuan. Konsentrasi klorofil dihitung dengan menggunakan formula sebagai berikut:

Total klorofil $(\mathrm{a}+\mathrm{b})=(8.02 \mathrm{E} 663+20.20 \mathrm{E} 645) / \mathrm{FW}$

Klorofil $\mathrm{a}=(12.7 \mathrm{E} 663-2.69 \mathrm{E} 645) / \mathrm{FW}$

Klorofil $b=(22.9 \mathrm{E} 645-4.68 \mathrm{E} 663) / \mathrm{FW}$ 
Keterangan :

a : Klorofil a

b : Klorofil b

E663 : Nilai absorban pada panjang gelombang $663 \mathrm{~nm}$

E645 : Nilai absorban pada panjang gelombang $645 \mathrm{~nm}$

FW : Fresh weight

\section{Pengukuran Fotosintesis}

Pengukuran dilakukan di rumah kaca sebanyak 2 kali pada tanggal 29 dan 30 Juli 2014 (minggu ke-4 pengamatan). Laju fotosintesis bersih $(P n)$ dan laju transpirasi $(T r)$ diukur menggunakan sistem fotosintesis portabel LI-COR 6400XT pada pukul 09:00 hingga 12:00. Pengukuran dilakukan pada daun ketiga hingga kelima dari bagian atas bibit (Yang et al. 2014). Sementara itu, pengukuran efisiensi penggunaan air (WUE) dilakukan dengan mengukur rasio dari nilai laju fotosintesis bersih dan laju transpirasi.

\section{Pengukuran Konduktansi Stomata Harian}

Pengukuran dilakukan dengan menggunakan leaf porometer pada daun ketiga hingga kelima dari bagian atas bibit (Yang et al., 2014). Pengukuran dilakukan satu kali pada tanggal 26 Juli 2014 dengan interval 2 jam dimulai dari pukul 09:00, 11:00, 13:00, 15:00, 17:00 (Li et al., 2007; Liu et al., 2012). Pengukuran dilakukan pada semua sampel perlakuan.

\section{Analisis Data}

Data hasil pengukuran tinggi, diameter, biomasa, laju fotosintesis, laju transpirasi, kandungan klorofil dan konduktansi stomata dianalisis menggunakan analisis tren.

\section{HASIL DAN PEMBAHASAN}

\section{Respon Perlakuan terhadap Perilaku Fisiologis Black Locust}

\section{Fotosintesis}

Perlakuan cekaman kekeringan dengan kapasitas lapang (KL) 30-40 \% menunjukkan penurunan fotosintesis sebesar 51,13\% pada bibit black locust dibandingkan dengan perlakuan dengan kondisi penyiraman yang baik (KL 70-80 \%) (Gambar 1). Berdasarkan Anjum et al. (2011a), beberapa penelitian telah menunjukkan penurunan aktivitas

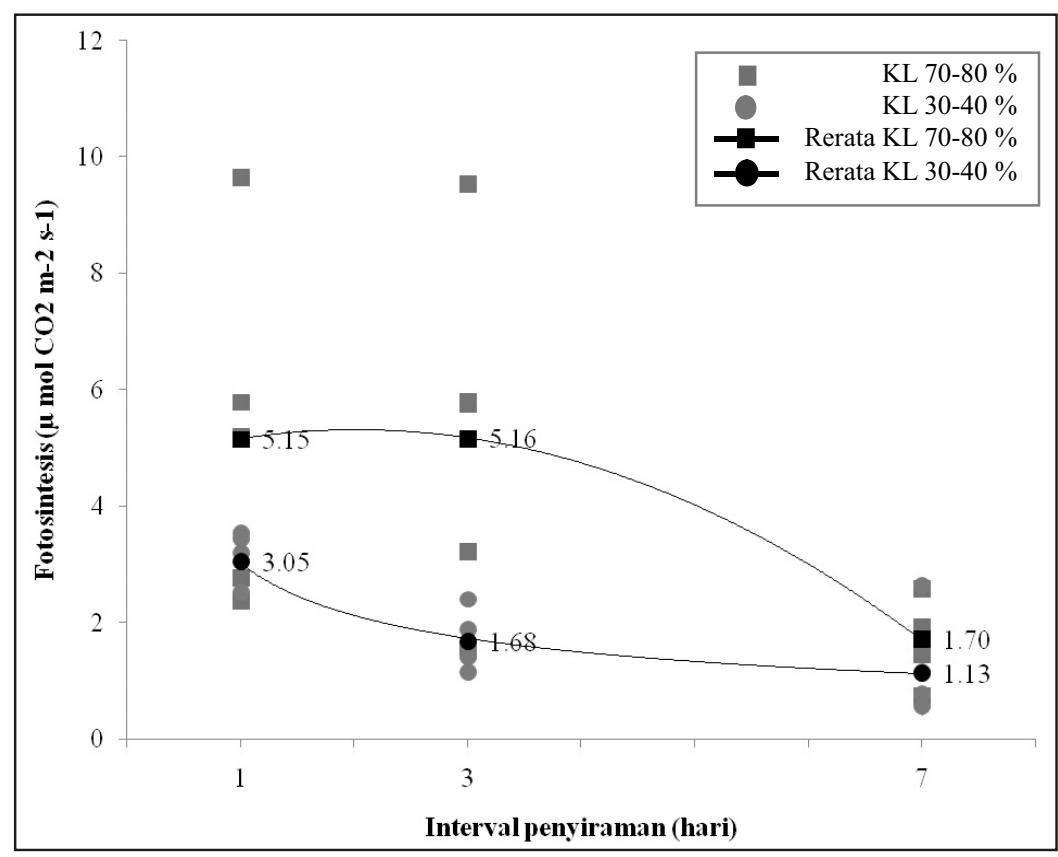

Gambar 1. Nilai fotosintesis pada perlakuan volume penyiraman dan interval penyiraman dari bibit black locust umur 6 bulan. 
fotosintesis pada cekaman kekeringan yang disebabkan karena mekanisme stomata maupun non stomata. Stomata merupakan pintu keluarnya air dan penyerapan $\mathrm{CO}_{2}$ dan penutupan stomata merupakan salah satu respon awal dari tanaman dalam menghadapi cekaman kekeringan yang akhirnya menyebabkan laju fotosintesis mengalami penurunan.

Penurunan fotosintesis terhadap cekaman kekeringan ini menurut Grant (2012) juga tak terlepas dari kinerja asam absisat (ABA) yang memiliki peran penting sebagai sinyal dari akar yang diangkut melalui pembuluh xilem dan terlibat dalam regulasi stomata selama tanaman mengalami kekeringan. Keberadaan ABA pada akar menurut Mahajan dan Tuteja (2005), dipengaruhi oleh pH yang meningkat pada pembuluh xilem akar dan selanjutnya diangkut ke tunas. Sehingga berdasarkan Lakitan (2013) akumulasi ABA pada daun menyebabkan stomata tertutup, yang menurut Grant (2012) akibatnya mengurangi difusi $\mathrm{CO}_{2}$ udara pada peristiwa karboksilasi sehingga menyebabkan penurunan fotosintesis. Lebih lanjut pembatasan non stomata sebagai respon dari penurunan proses fotosintesis juga terjadi, seperti penurunan efisiensi karboksilasi, penurunan regenerasi ribulose-1.5-biophosphate (PuBP), penurunan jumlah Rubisco fungsional atau menghambat aktivitas fungsional dari fotosistem II (PSII) (Zlatev dan Lidon, 2012).

Fotosintesis bibit black locust pada perlakuan interval penyiraman menunjukkan semakin lama interval penyiraman maka fotosintesis akan semakin rendah (Gambar 1), dan fotosintesis mengalami penurunan paling dominan sampai $65,5 \%$ pada 7 hari sekali penyiraman. Berawal dari semakin lamanya penyiraman sehingga persediaan (penyimpanan) air semakin sedikit. Akibat selanjutnya, menurut Taiz dan Zeiger (2002), daun dan akar tanaman semakin lama akan mengalami dehidrasi air sehingga memicu penurunan larutan pada sel penjaga dan tekanan turgor, yang mengakibatkan stomata menutup. Penutupan stomata akan menghambat pertukaran gas dan fotosintesis pada tanaman, yang oleh Meng et al. (2014) dinyatakan bahwa

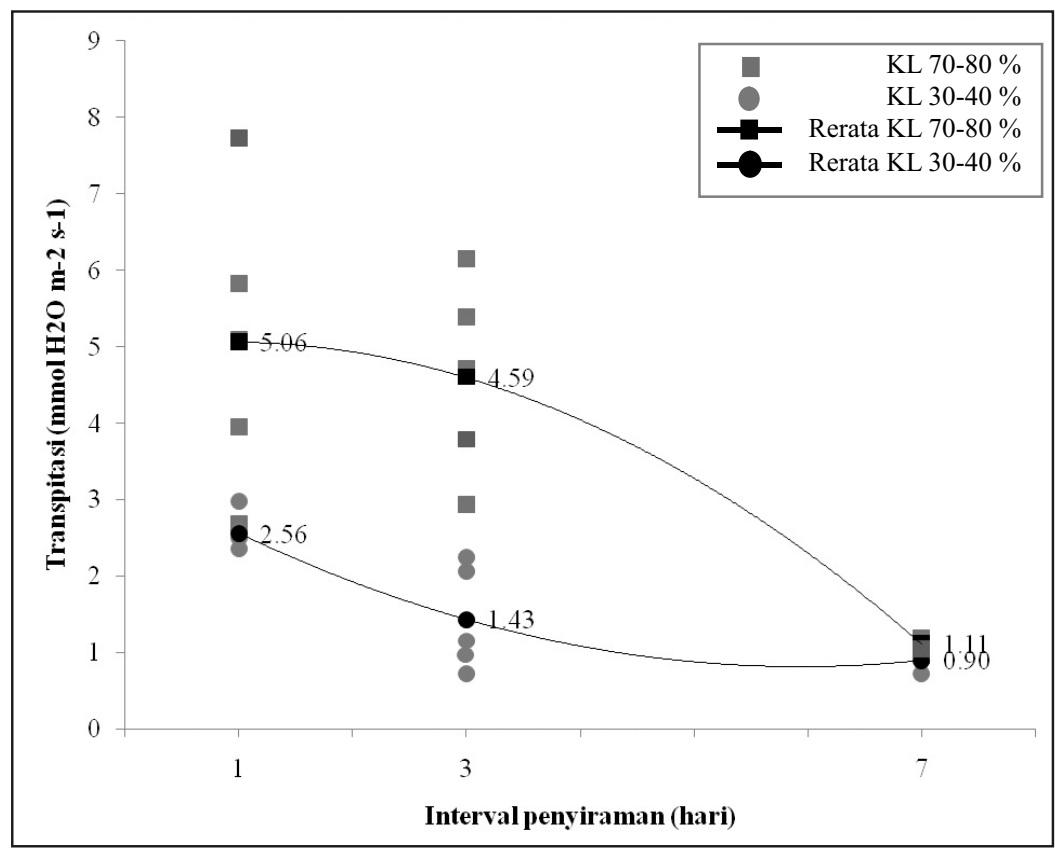

Gambar 2. Nilai transpirasi pada perlakuan volume penyiraman dan interval penyiraman dari bibit black locust umur 6 bulan 
fotosintesis ditentukan oleh fiksasi $\mathrm{CO}_{2}$ serta $\mathrm{CO}_{2}$ yang masuk ke tanaman melalui stomata. Cekaman kekeringan juga menurunkan laju fotosintesis bersih sebesar 33,22 \% pada jagung (Anjum et al., 2011b). Sama halnya pada bibit Bauhinia forficata (Sanches dan Silva, 2013) bahwa kondisi defisit air (cekaman kekeringan) mampu menurunkan laju fotosintesis bersih sebanyak $61,8 \%$.

\section{Transpirasi}

Transpirasi bibit black locust mengalami penurunan pada perlakuan volume penyiraman. Semakin rendah volume penyiraman yang diberikan (cekaman kekeringan) maka transpirasi juga akan semakin rendah dan menurun 54,21\% (Gambar 2). Sama halnya pada perlakuan interval penyiraman, transpirasi mengalami penurunan $73,62 \%$ dengan semakin lamanya interval penyiraman (Gambar 2).

Penurunan transpirasi ini terjadi diduga sebagai respon tanaman dalam menghadapi kekeringan, sehingga untuk menghindari kehilangan air, tanaman mengurangi laju transpirasinya. Penurunan laju transpirasi ini ditandai dengan penyempitan dan/atau penutupan stomata, dan sebagian besar air yang keluar pada proses transpirasi adalah melalui stomata (Pallardy, 2008). Pembukaan dan penutupan stomata ditentukan oleh tekanan turgor dari kedua sel penjaga, sementara itu tekanan turgor dipengaruhi oleh banyaknya air yang masuk ke sel penjaga (Lakitan, 2013). Cekaman kekeringan juga menyebabkan distribusi air ke sel penjaga menurun sehingga terjadi penurunan tekanan turgor yang berdampak pada penutupan stomata. Penurunan transpirasi ini juga terjadi pada jagung (Zea mays L.) dengan transpirasi tanaman jagung pada kondisi kekeringan yang lebih rendah jika dibandingkan dengan kondisi cukup air, baik pada tanaman jagung yang diberi mikoriza maupun tidak diberi mikoriza (Zhu et al., 2012).

\section{Water Use Efficiency (WUE)}

WUE menggambarkan hubungan antara produksi yang dihasilkan tanaman dan konsumsi air, serta bisa juga didefinisikan sebagai rasio antara berat kering yang dihasilkan terhadap air yang digunakan pada saat evapotranspirasi atau evaporasi (jika dikaitkan

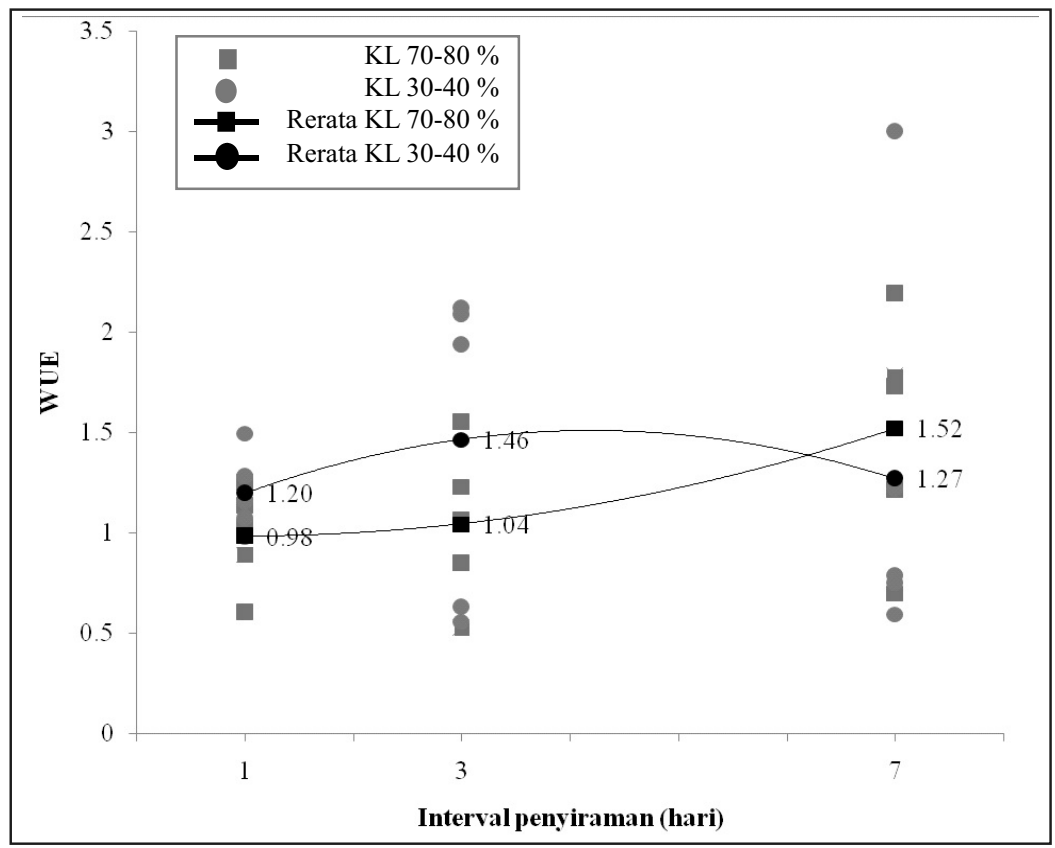

Gambar 3. Nilai water use efficiency (WUE) pada perlakuan volume penyiraman dan interval penyiraman dari bibit black locust umur 6 bulan 
dalam skala hutan) (Kramer dan Kozlowski, 1979). Fotosintesis dan transpirasi mengalami penurunan dengan semakin rendahnya volume penyiraman serta semakin lamanya interval penyiraman, sementara tren WUE mengalami peningkatan pada volume penyiraman 70-80 \% dan semakin lama interval penyiraman (Gambar 3). WUE sering mengalami peningkatan ketika terjadi keterbatasan air (Grant, 2012). Dampak dari menurunnya WUE ini adalah menutupnya stomata (tekanan turgor pada sel penjaga menurun) dan menurunnya transpirasi (Gambar 2). Sementara pada volume penyiraman 30-40 \% WUE mengalami peningkatan pada interval penyiraman 3 hari dan mengalami penurunan pada interval penyiraman 7 hari.

Penelitian ini sejalan dengan penelitian sebelumnya bahwa defisit air meningkatkan WUE bibit black locust pada kondisi ketersediaan $\mathrm{N}$ yang rendah maupun tinggi (Liu et al., 2012). Hal ini juga sejalan dengan penelitian Novriyanti et al., (2012) bahwa kondisi stres kekeringan meningkatkan WUE pada bibit Acacia (A. mangium dan A. auriculiformis), dan di saat bersamaan menurunkan laju fotosintesis, laju transpirasi serta konduktansi stomata. Hal ini juga mengindikasikan bahwa jenis Acacia termasuk ke dalam jenis toleran terhadap stres kekeringan. Berbeda halnya dengan penelitian cekaman kekeringan pada bibit Eucalyptus (E. camaldulensis, E. urophylla, E. grandis, dan E. globulus) yang mengalami penurunan WUE, peningkatan laju fotosintesis, laju transpirasi dan konduktansi stomata ketika mengalami stres kekeringan. Penelitian pada tanaman jagung juga memiliki respon berbeda yakni adanya defisit air secara signifikan menurunkan WUE baik pada tanaman jagung yang diberi mikoriza maupun yang tidak (Zhu et al., 2012).

\section{Konduktansi Stomata Harian}

Konduktansi stomata harian pada perlakuan volume penyiraman menunjukkan bahwa tanaman dengan kondisi kekeringan (KL 30-40 \%) dan tanaman dengan kondisi cukup air (KL 70-80 \%) memiliki tren yang sama yakni mengalami kenaikan dan/atau stabil pada pukul 09.00-11.00 JST dan mulai mengalami penurunan konduktansi stomata pada pukul 13.00 JST. Sementara itu, tren konduktansi stomata pada tanaman dengan kondisi kekeringan (KL 30-40 \%) tercatat lebih rendah dibandingkan dengan tren konduktansi stomata pada tanaman dengan kondisi cukup air (KL 70-80 \%) (Gambar 4a). Hal ini sejalan dengan penelitian Liu et al. (2012) bahwa stress kekeringan menurunkan tren konduktansi stomata harian pada bibit black locust pada level cukup nitrogen dan kekurangan nitrogen, serta sejalan dengan penelitian Zhu et al. (2012) bahwa kondisi kekeringan menurunkan konduktansi stomata pada tanaman jagung yang diberi mikoriza maupun tidak diberi mikoriza. Perlakuan interval penyiraman (Gambar 4b) menunjukkan bahwa tanaman yang disiram setiap 7 hari sekali memiliki konduktansi stomata paling rendah dibandingkan tanaman yang disiram setiap 3 hari sekali yang menempati urutan kedua serta tanaman yang disiram setiap hari yang menempati tren paling tinggi. Sementara itu, kenaikan maupun penurunan konduktansi stomata terlihat beragam. Konduktansi stomata di bawah cekaman kekeringan yang ditunjukkan pada penyiraman 7 hari sekali menunjukkan level rendah dibandingkan dengan yang lainnya. Hal ini sejalan dengan penelitian Souza et al. (2004) yang mengungkapkan bahwa defisit air menurunkan konduktansi stomata pada bunga matahari dan tanaman bit gula, serta pada Acacia harphophylla (Farquhar, 1989). 


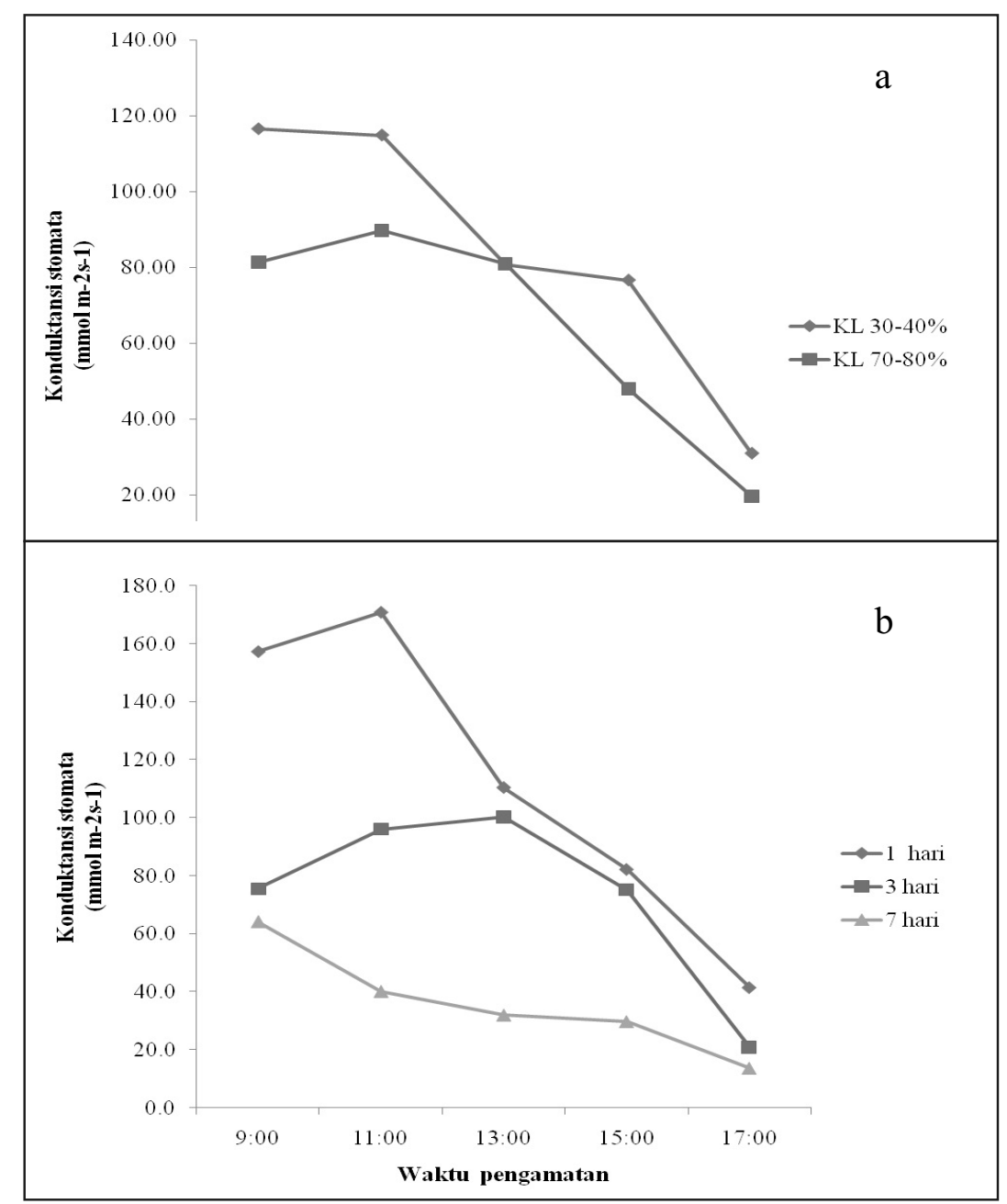

Gambar 4. a) Konduktansi stomata harian pada perlakuan volume penyiraman (KL= kapasitas lapangan) pada bibit black locust umur 6 bulan; b) Konduktansi stomata harian pada perlakuan interval penyiraman pada bibit black locust umur 6 bulan

Cekaman kekeringan melalui perlakuan volume penyiraman dan interval penyiraman mengakibatkan penurunan konduktansi stomata pada bibit black locust. Hal ini merupakan upaya tanaman untuk menghindari kehilangan air berlebih pada tubuh tanaman melalui proses transpirasi. Adapun pergerakan bukaan stomata tergantung pada tekanan turgor dari sel penjaga. Stomata akan membuka ketika tekanan turgor meningkat (Lakitan, 2013). Semakin banyak jumlah ion kalium yang masuk ke sel penjaga maka semakin besar stomata terbuka. Pada kondisi kekeringan, tekanan turgor mengalami penurunan dan memicu akumulasi ABA ke stomata yang berasal dari akar tanaman melalui pembuluh xilem dan menurunkan jumlah ion kalium, dan menyebabkan stomata tertutup (Lakitan, 2013). Menurut Mangavalan dan Nguyen (2012), upaya pengontrolan konduktansi stomata melalui pengeringan sebagian akar tanaman dan pengaturan defisit irigasi yang dilakukan pada sayuran dan jagung, menunjukkan bahwa penurunan konduktansi stomata pada pengaturan defisit irigasi akan meningkatkan WUE dan produktivitas, setara dengan kondisi tanpa stres. Hal yang sama juga terjadi pada penelitian ini dimana pada perlakuan volume penyiraman maupun interval penyiraman, kondisi defisit air meningkatkan WUE dan menurunkan konduktansi stomata. 

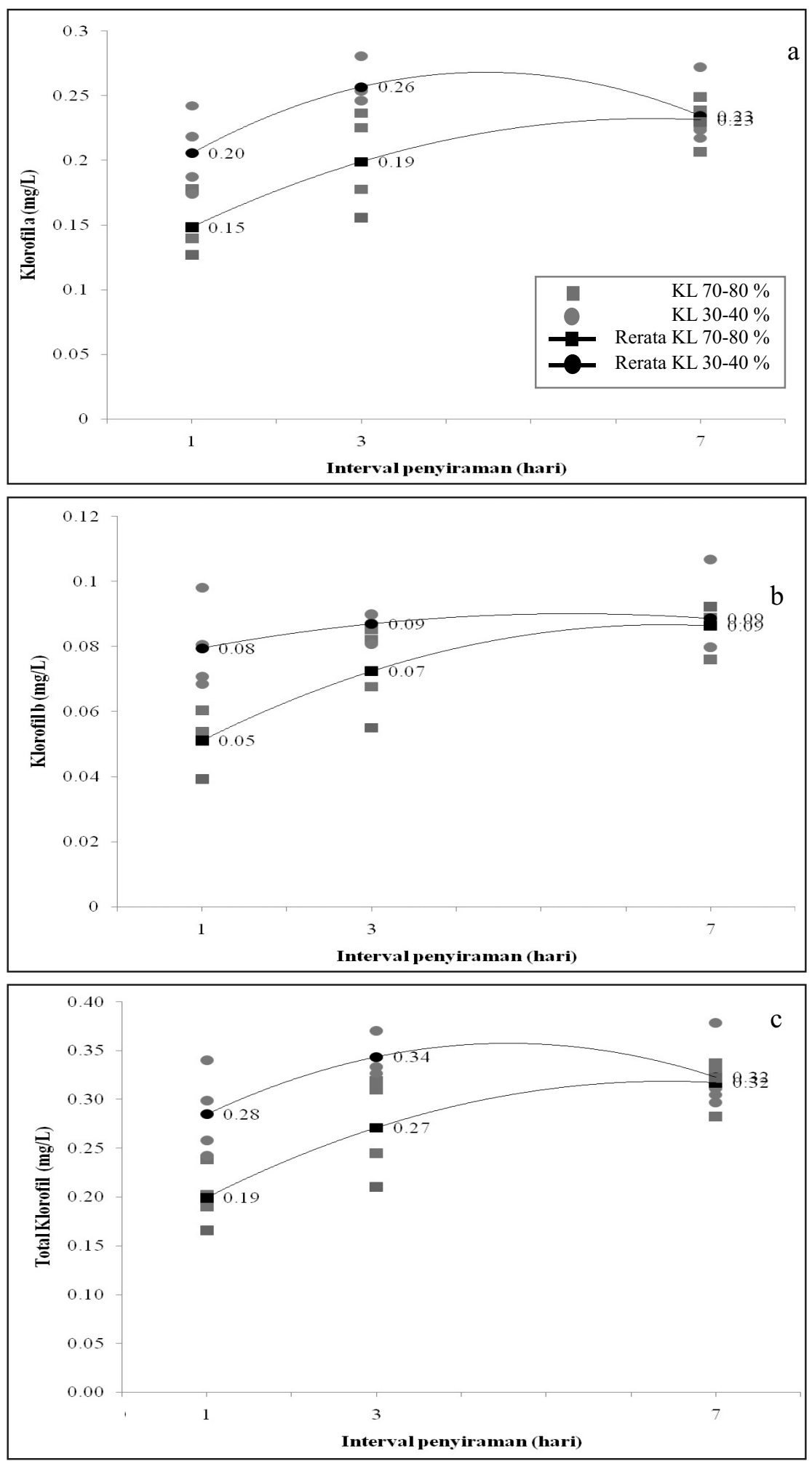

Gambar 5. Nilai kandungan klorofil pada perlakuan volume penyiraman dan interval penyiraman dari bibit black locust umur 6 bulan, a) klorofil a; b) klorofil b; serta c) total klorofil

\section{Kandungan Klorofil}

Klorofil merupakan komponen utama kloroplas untuk fotosintesis, dan kandungan klorofil relatif memiliki hubungan yang positif terhadap laju fotosintesis. Pada umumnya semakin tinggi kandungan klorofil maka akan semakin tinggi pula 
laju fotosintesis (Anjum et al., 2011a). Namun demikian, pada penelitian ini menunjukkan hasil yang kontradiktif, tercatat bahwa kandungan klorofil mengalami peningkatan pada kondisi defisit air (KL $30-40 \%$ dan interval penyiraman 7 hari) (Gambar 5), sementara pada saat yang sama laju fotosintesis mengalami penurunan (Gambar 1). Hasil penelitian juga tidak sejalan dengan penelitian Zhu et al. (2012) yang mencatat bahwa defisit air menurunkan kandungan klorofil pada jagung yang tidak diberi mikoriza. Namun pada penelitian Mensah et al.
(2006) menunjukkan bahwa kandungan klorofil meningkat pada kondisi defisit air pada tanaman wijen dan hal ini menandakan kemampuannya untuk tetap mensintesis lebih banyak klorofil pada kondisi kekeringan, yang merupakan indikator yang baik untuk toleransi terhadap kekeringan.

\section{Respon Perlakuan terhadap Pertumbuhan Black Locust}

Pertumbuhan tanaman merupakan fungsi dari interaksi kompleks antara sumber dan keterbatasan sink dari dua bagian utama tanaman, sistem akar, dan
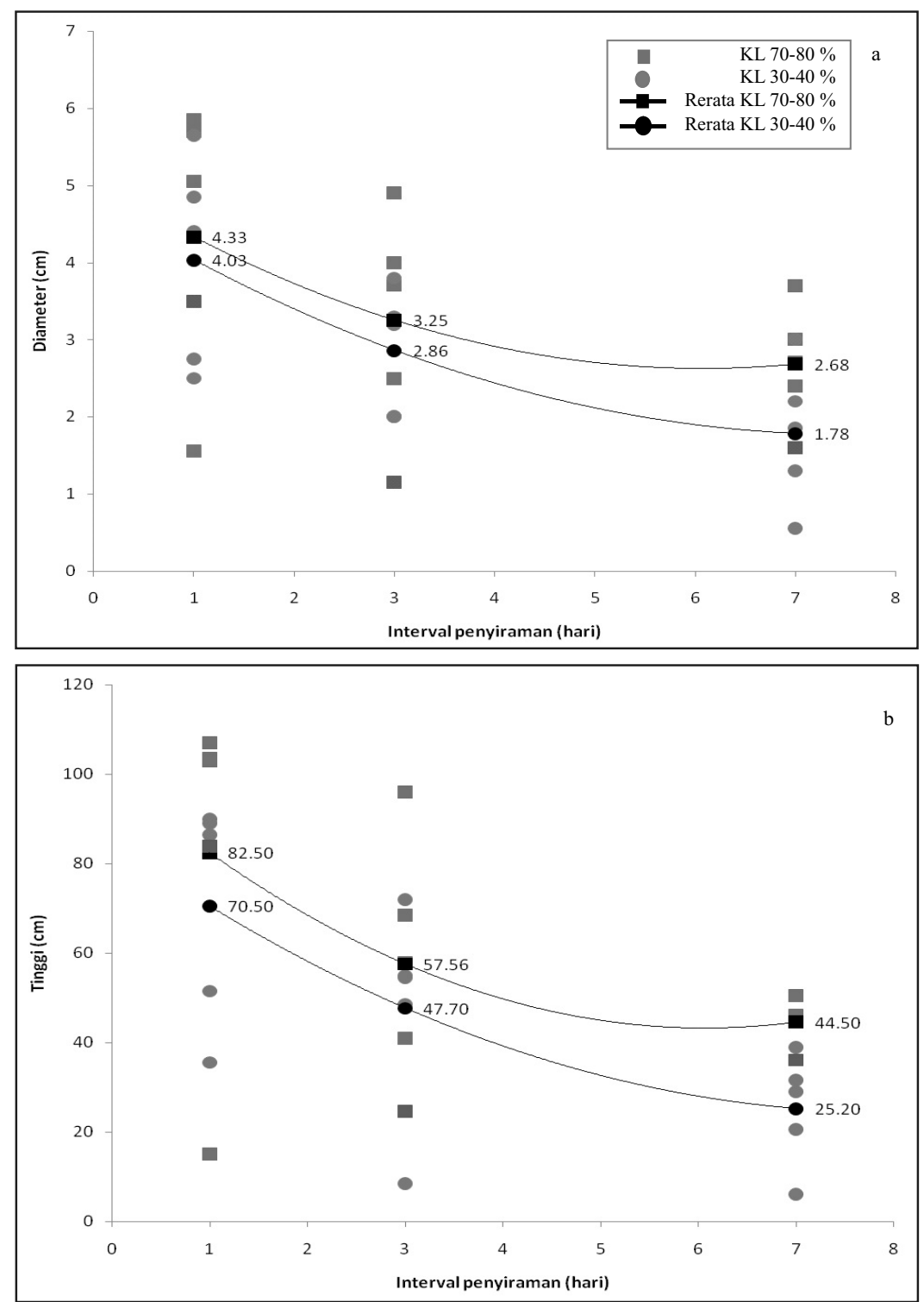

Gambar 6. Pertumbuhan tinggi dan diameter pada perlakuan volume penyiraman dan interval penyiraman dari bibit black locust umur 6 bulan 
tunas, yang membangun keseimbangan fungsional. Dibandingkan faktor lingkungan yang lainnya, defisit air yang terjadi secara permanen maupun sementara lebih mempengaruhi tumbuh kembang tanaman (Anjum et al., 2011a).

Pada penelitian ini terlihat bahwa pertumbuhan diameter dan tinggi black locust mengalami penurunan dengan meningkatnya level kekeringan baik pada perlakuan volume penyiraman maupun interval penyiraman (Gambar 6). Tren ini sejalan dengan penelitian Yang et al. (2014) yang menyata- kan bahwa semakin sedikit air yang diberikan kepada bibit black locust maka pertumbuhan diameter dan tinggi akan semakin rendah baik jika diberi mikoriza maupun tidak diberi mikoriza, serta sejalan dengan penelitian Okon (2013) yang menunjukkan bahwa interval penyiraman yang semakin lama akan menurunkan pertumbuhan tanaman kacang tunggak.

Pertumbuhan mampu dicapai melalui pembelahan, pembesaran dan diferensiasi sel, dan melibatkan faktor genetik, fisiologi, ekologi, morfologi serta interaksi kompleksnya. Kualitas dan kuantitas
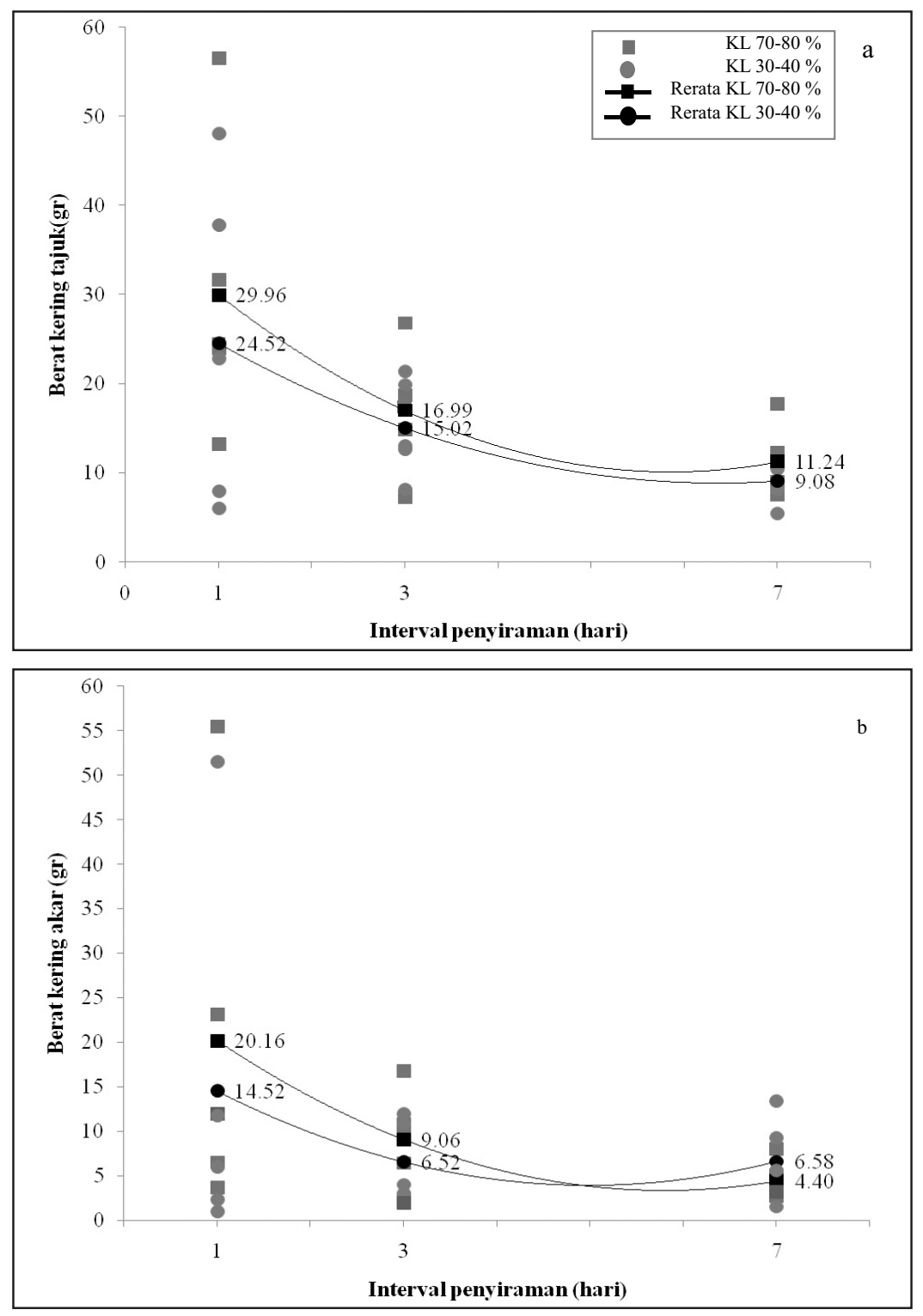

Gambar 7. Berat kering tajuk dan berat kering akar pada perlakuan volume penyiraman dan interval penyiraman dari bibit black locust umur 6 bulan 
pertumbuhan tergantung pada aktivitas yang terjadi pada tubuh tanaman yang dipengaruhi oleh ketersediaan air tanaman. Kondisi defisit air yang pada penelitian ini menurunkan pertumbuhan diameter dan tinggi dapat disebabkan karena turunnya tekanan turgor (Farooq et al., 2009); terhambatnya perpanjangan sel karena adanya gangguan aliran air dari xilem ke sekitar sel-sel yang memanjang (Nonami, 1998); serta terhambatnya mitosis dan pembesaran sel (Anjum et al., 2011a).

Berat kering tajuk dan akar bibit black locust memiliki tren yang sama yakni mengalami penurunan pada kondisi cekaman kekeringan baik pada perlakuan volume penyiraman maupun pada perlakuan interval penyiraman, kecuali pada volume penyiraman 30-40\% dengan interval penyiraman 7 hari yang mengalami peningkatan (Gambar 7). Hal ini sejalan dengan penelitian Zeid dan Shedeed (2006) yang mencatat bahwa potensi perkecambahan, perpanjangan hipokotil, berat kering, dan berat basah tunas dan akar dari tanaman alfalfa mengalami penurunan pada kondisi defisit air.
Cekaman kekeringan menghambat produksi berat kering terutama melalui efek inhibitornya dari perluasan dan pengembangan daun, sehingga menurunkan penangkapan cahaya. Penutupan stomata sebagai respon rendahnya potensi air yang menurunkan pengambilan $\mathrm{CO}_{2}$ dari udara, membuat proses fotosintesis menurun (Anjum et al., 2011a) juga akan terpengaruh dengan adanya gangguan perluasan daun. Pada penelitian ini, penurunan berat kering tajuk dan akar terjadi dengan semakin lamanya interval penyiraman dan semakin rendahnya volume air yang diberikan (Gambar 7).

Rasio tajuk akar pada volume penyiraman 30-40 $\%$ mengalami penurunan dengan semakin lama interval penyiraman (Gambar 8). Hal ini sejalan dengan penelitian Nejad et al., (2010) yang mencatat bahwa defisit air memberikan pengaruh terhadap penurunan rasio tajuk akar pada tanaman jagung. Pada kondisi kekeringan, alokasi biomassa ke akar biasanya meningkat untuk digunakan sebagai upaya mengakses sumber air (Zlatev dan Lidon, 2012). Kramer dan Kozlowski (1979) juga mencatat

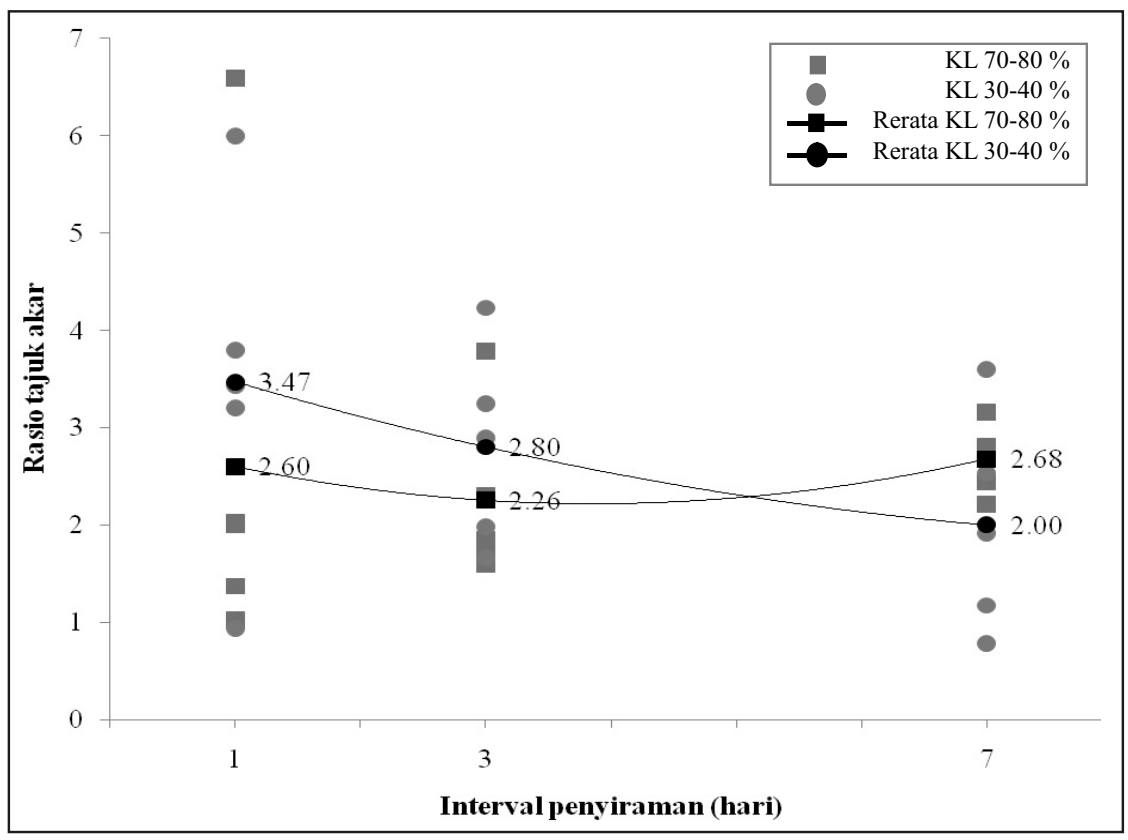

Gambar 8. Nilai rasio tajuk akar pada perlakuan volume penyiraman dan interval penyiraman dari bibit black locust umur 6 bulan 
kemampuan bertahan bibit cemara douglas dan Pinus ponderosa pada kondisi kekeringan dengan cara memperluas sistem perakaran dan mengurangi rasio tajuk akar. Sementara pada volume penyiraman 70-80 \%, rasio tajuk akar mengalami penurunan pada interval penyiraman 3 hari dan selanjutnya meningkat pada interval penyiraman 7 hari (Gambar 8). Penurunan ini terjadi karena upaya black locust memperluas sistem perakaran untuk pengambilan air, sedangkan peningkatan terjadi diperkirakan dalam upaya memanfaatkan pengambilan air untuk pertumbuhan tajuk.

Seluruh parameter (fotosintesis, transpirasi, WUE, kandungan klorofil dan pertumbuhan) yang diuraikan menggunakan analisis tren ternyata menunjukkan hasil yang sama, yakni pada interval penyiraman 1 hari dan 3 hari variasi nilai setiap individu cukup tinggi. Hal ini diduga karena respon bibit black locust dalam menghadapi kondisi tersebut berbeda-beda disebabkan potensi internal bibit dan ketersediaan air yang berbeda yang mempengaruhi ekspresi pertumbuhannya. Sementara itu, pada interval penyiraman 7 hari yakni kondisi cekaman kekeringan paling tinggi, respon setiap individu dalam menghadapi kondisi cekaman kekeringan relatif sama yakni mengalami penurunan. Hal ini diduga karena keterbatasan ketersediaan air yang membuat seluruh bibit black locust mengalami kondisi kekurangan dan kondisi tercekam kekeringan yang mengakibatkan sistem fisiologi, metabolisme dan pertumbuhan bibit black locust cenderung menurun.

\section{Implikasi Bibit black Locust pada Kondisi Cekaman Kekeringan dalam Upaya Mempelajari Potensi Keinvasifannya}

Kemampuan bibit black locust dalam menghadapi cekaman kekeringan terlihat dari kemampuannya dalam meningkatkan WUE pada saat defisit air
(Gambar 3). Peningkatan WUE akan memicu penutupan stomata, yang didahului oleh sinyal ABA dari akar ke daun. Kemudian, kondisi ini akan membuat bibit black locust menurunkan konduktansi stomata, laju transpirasi (Gambar 2 dan Gambar 4), dan terakhir menurunkan laju fotosintesis (Gambar 1) serta pertumbuhan (Gambar 6). Hal ini senada dengan hasil Novriyanti et al. (2012) yang menjelaskan bahwa peningkatan WUE merupakan salah satu upaya suatu tanaman toleran terhadap kekeringan.

Penurunan pertumbuhan bibit black locust pada kondisi cekaman kekeringan adalah upaya bibit dalam menghadapi stres. Dengan menurunkan pertumbuhan, diharapkan bibit tetap mampu mempertahankan fungsi fisiologisnya untuk bertahan hidup. Beberapa literatur mencatat bahwa black locust akan tumbuh baik bahkan invasif pada kondisi tanah yang miskin nutrisi, daerah hangat dan kering, serta daerah yang kurang penjagaan (Enenscu dan Danescu, 2013). Kemampuan black locust dalam menghadapi stres juga tak lepas dari kemampuan black locust dalam memfiksasi nitrogen. Dengan kemampuannya ini, black locust mampu tumbuh pada lahan yang tidak subur sekalipun, sekaligus jenis ini mampu menjadi penyedia nitrogen bagi tanaman lain pada lahan yang cukup luas (Rahmanov, 2009).

Kemampuan black locust tumbuh dengan baik dan mampu tumbuh pada lahan marginal juga disebabkan karena pada waktu berumur muda, kayu black locust cenderung memiliki kandungan nitrogen yang tinggi. Selain itu, kemampuan black locust dalam menghasilkan serasah yang banyak dan terdekomposisi dengan cepat membuat jenis ini mampu menyediakan sumber nutrisi bagi tanaman lain (humus). Black locust mampu membentuk belukar dengan Reynoutria japonica dan $R$. sachalinensis, sementara benih pinus mengalami 
kematian pada saat ditanam di bawah naungan black locust. Keterbatasan jenis yang berada di sekitar black locust juga dipengaruhi oleh alelopati yang dibawa daunnya dan terdekomposisi seperti robinetin, myricetin, quercetin (Rahmanov, 2009). Kemampuan black locust ini yang membuatnya menjadi kategori jenis invasif. Potensi keinvasifan ini juga didukung oleh kemampuan jenis ini memperbanyak diri dengan cara aseksual (stump sprouting dan root suckering) dan seksual (penghasil biji yang banyak dan cenderung membentuk seed bank). Selain itu, black locust ditemukan memiliki respon positif yang kuat terhadap peningkatan $\mathrm{CO}_{2}$ (Motta et al., 2009).

Black locust memang memiliki nilai ekonomi yang cukup baik dari aspek vitalitas, jumlah benih melimpah serta kemampuan memperbaiki tanah, sehingga membuat jenis ini banyak ditanam. Namun bila pertumbuhannya tidak dikontrol akan menjadi masalah. Proses eradikasi untuk mengembalikan komunitas tanaman aslinya sangat sulit, membutuhkan biaya dan waktu. Jika menggantungkan pada suksesi alami maka akan sangat lama, pada habitat aslinya tanaman ini mampu digantikan setelah berumur 15-30 tahun dengan jenis pohon yang lebih kompetitif (Vítková et al., 2015).

Kemampuan black locust tumbuh cepat membuatnya mendominasi kanopi suatu lahan hutan dalam hal menguasai sumber energi cahaya, sehingga membuat pertumbuhan jenis lain terhambat (Dreiss dan Volin, 2013). Kanopi yang padat dari black locust menghambat pertumbuhan bibit Pinus thunbergii di fase awal pertumbuhan pada tahap suksesi (Taniguchi et al., 2007). Oleh karenanya diperlukan beberapa pertimbangan yang matang untuk menanam black locust, baik untuk tujuan memperbaiki lahan terdegradasi maupun untuk pertanaman, untuk menghindari masalah baru.

\section{KESIMPULAN}

Hasil penelitian perlakuan cekaman kekeringan terhadap tanaman black locust menunjukkan bahwa :

1. Semakin rendah volume penyiraman maka laju fotosintesis, laju transpirasi, konduktansi stomata, serta pertumbuhan (tinggi, diameter, berat kering tajuk, dan akar) akan semakin rendah, sementara untuk WUE, kandungan klorofil maupun rasio tajuk akar semakin tinggi.

2. Semakin lama interval penyiraman maka laju fotosintesis, laju transpirasi, konduktansi stomata, serta pertumbuhan (tinggi, diameter, berat kering tajuk, akar, rasio tajuk akar) akan semakin rendah, sementara WUE dan kandungan klorofil semakin tinggi.

3. Peningkatan WUE dan kandungan klorofil pada kondisi cekaman kekeringan menegaskan bahwa jenis ini mampu beradaptasi pada kondisi cekaman kekeringan.

\section{DAFTAR PUSTAKA}

Anjum SA, Xie X., Wang L, Saleem MF, Man C, \& Lei W. 2011a. Morphological, physiological and biochemical responses of plants to drought stress. African Journal of Agricultural Research 6(9), 2026-2032.

Anjum SA, Wang LC, Farooq M, Hussain M, Xue LL, \& Zou CM. 2011b. Brassinolide application improves the drought tolerance in maize through modulation of enzymatic antioxidants and leaf gas exchange. J. Agronomy \& Crop Science 197, 177-185.

Chaves M M, Pereira JS, Maroco J, Rodriggues ML, Ricardo CPP, Osorio ML, Calvarho I, Faria T, \& Pinheiro C. 2002. How plants cope with water stress in the field? Photosynthesis and growth. Annals of Botany 89(7), 907-916.

Dreiss LM \& Volin JC. 2013. Influence of leaf phenology and site nitrogen on invasive species establishment in temperate deciduous forest understories. Forests Ecology and Management 296, 1-8. 
Enescu CM \& Danescu A. 2013. Black locust (Robinia pseudoacacia L.) - An invasif neophyte in the conventional land reclamation flora in Romania. Bulletin of the Transilvania University of Braso 6(55), 23-30.

Farooq M, Wahid A, Kobayashi N, Fujita D, \& Basra SMA. 2009. Plant drought stress: Effects, mechanism and management. Agron.Sustain.Dev. 29, 185-212.

Farquhar GD, Wong SC, Evans JR. \& Hubick KT. 1989. Photosynthesis and gas exchange. Dalam : Plants under Stress. Jones HG, Flowers TJ, \& Jones MB (Ed). Cambridge University Press, New York. 46-93.

Gomez TD \& Wagner MR. 2001. Culture and use of black locust. HortTecnology. $<\mathrm{http}$ //horttech.ashspublications.org/content/11/ 2/279.full.pdf + html $>$ (1 Maret 2014).

Gonzalez-Garcia S, Gasol CM, Moreira MT, Gabarrell X, Pons JRI, \& Feijoo G. 2011. Environmental assesment of black locust (Robinia pseudoacacia L.)-based ethanol as potential transport fuel. Int. J. Life Cycle Assess 16, 465-477.

Grant OM. 2012. Understanding and exploiting the impact of drought stress on plant physiology. Dalam : Abiotic stress responses in plants. Ahmad $\mathrm{P} \&$ Prasad MNV (Ed). Springer, New York. 89-104.

Jung SC, Matsushita N, Wu BY, Kondo N, Shiraishi A, \& Hogetsu T. 2009. Reproduction of a Robinia pseudoacacia population in a coastal Pinus thunbergii windbreak along the Kujukurihama Coast Japan. J For Res 14,101-110.

Kramer PJ \& Kozlowski TT. 1979. Photosynthesis to the importance of water and the process of transpiration, Dalam : Physiology of Woody Plants. Academic Press, London. 163-444.

Lakitan B. 2013. Dasar-Dasar Fisiologi Tumbuhan. Rajawali Press, Jakarta. 35-62.

Lee CS, Cho HJ, \& Yi H. Stand dynamics of introduced black locust (Robinia pseudoacacia L.) plantation under different disturbance regimes in Korea. 2004. Forest Ecology and Management 189, 281-293.

Li KR, Wang HH, Han G, Wang QJ, \& Fan J. 2008. Effects of brassinoline on the survival, growth, and drought resistance of Robinia pseudoacacia seedlings under water-stress. New Forests 35, 255-266.
Liu X, Fan Y, Long J, Wei R, Kjelgren R, Gong C \& Zhao J. 2012. Effects of soils water and nitrogen availability on photosynthesis and water use efficiency of Robinia pseudoacacia seedlings. Journal of Environmental Sciences 25(3), 585-595.

Mahajan S \& Tuteja N. 2005. Cold, salinity and drought stress: An overview. Archives of biochemistry and biophysics 444, 139-158.

Manavalan LP, \& Nguyen HT. 2012. Drought tolerance in crops: Physiology to genomics. Dalam : Plant Stress Physiology. Shabala S (Ed). UK: CAB International, 1-23.

Masaka K, Yamada K, KoyamaY, Sato H, Kon H \& Torita H. 2010. Changes in size of soil seed bank in Robinia pseudoacacia L. (Leguminosae), an exotic tall tree species in Japan: impacts of stand growth and apicultural Utilization. Forest Ecology and Management 260, 780-786.

Mazher AAM, Yassen AA, \& Zaghloul SM. 2007. Influence of foliar application of potassium on growth and chemical composition of Bauhia variegate seedlings under different irrigation intervals. World Journal of Agriculture Sciences 3(1), 23-31.

Meng F, Peng M, Pang H, \& Huang F. 2014. Comparison of photosynthesis and leaf ultrastructure on two black locust (Robinia pseudoacacia L.). Biochemical Systematics and Ecology 55, 170-175.

Mensah JK, Obadoni BO, Eruotor PG, \& Onome-Irieguna F. 2006. Simulated flooding and drought effects on germination, growth, and yield parameters of sesame (Sesamum indicum L. African Journal of Biotechnology $\mathbf{5}$ (13), 1249-1253.

Micco VD \& Aronne G. 2012. Morpho-anatomical traits for plant adaptation to drought. Dalam : Plant Responses to Drought Stress from Morphological to Molecular Features. Aroca R (Ed). Springer-Verlag Berlin Heidelberg, Germany. 37-61.

Motta R, Nola P, \& Berretti R. 2009. The rise and fall of black locust (Robinia pseudoacacia L.) in the "Siro Negri" forest reserve (Lombardy, Italy): lessons and future uncertainties. Ann. For. Sci. 66, 410.

Mona \& Amin A. 2013. Study of the fertigation requirements for some woody trees. Journal of Applied Sciences Research 9(1), 284-293. 
Moshki A \& Lamersdorf NP. 2011. Growth and nutrient status of introduced black locust (Robinia pseudoacacia L.) afforestation in arid and semi arid areas of Iran. Research Journal of Environmental Sciences 5, 259-268.

Nilsen ET \& Orcutt DM. 1996. The physiology of plants under stress: Abiotic Factors. U.S.: John Wiley and Sons.Inc. 279-357.

Nishizawa T. 2013. Method of chlorophyll measurement. Direct Study. Laboratory of Horticulture. Yamagata University. Japan.

Nejad TS, Bakhshande A, Nasab SB, \& Payande K. 2010. Effect of drought oon corn root growth. Report and Opinion. $<\mathrm{http}: / /$ www.sciencepub.net $>$.

Nonami H. 1998. Plant water relations and control of cell elongation at low water potentials. Journal of Plant Research 111, 373-382.

Novriyanti E, Watanabe M, Makoto K, Takeda T, Hashidoko Y, \& Koike T. 2012. Photosynthetic nitrogen- and water-use efficiency of acacia and eucalypt seedlings as afforestation species. Photosynthetica 50(2), 273-281.

Okon JE. 2013. Effect of water stress on some growth aspects of two varieties of cowpea, Vigna unguiculata (L.) Walp Fabaceae. Bull. Env. Pharmacol. Life Sci. 2(5), 69-74.

Pallardy SG. 2008. Transpiration and plant water balance. Dalam Physiology of Woody Plants. $3^{\text {rd }}$ edition. Elsevier-London, UK. 25-366.

Rahmonov O. 2009. The chemical composition of plant litter of black locust (Robinia pseudoacacia L.) and its ecological role in sandy ecosystems. Acta Ecologica Sinica 29, 237-243.

Redei K, Csiha I, Keseru Z, Vegh AK, \& Gyori J. 2012. The silviculture of black locust (Robinia pseudoacacia L.) in Hungary : A Review. SEEFOR 2(2), 101-107.

Sabo AE. 2000. Robinia pseudoacacia invasions and control in North America and Europe. Restoration and reclamation review. Student On-Line Journal, 6(3), 1-9.

Sanches RFE \& Silva EAD. 2013. Changes in leaf water potential and photosynthesis of Bauhinia forficata Link under water deficit and after rehydration. Hoehnea 40(1), 181-190.
Souza GM, Olivera RFD \& Mendes VJ. 2004. Temporal dynamics of stomatal conductance of plants under water deficit: Can homeostasis be improved by more complex dynamics? Brazilian Archives of Biology and Technology, an International Journal 47(3), 423-431.

Taiz, L \& Zeiger E. 2002. Plant Physiology. U.S.: Sinauer Associates. 33-67.

Taniguchi T, Tamai S, Yamanaka N \& Futai K. 2007. Inhibition of the regeneration of Japanese Black Pine (Pinus thunbergii) by black locust (Robinia pseudoacacia) in Coastal Sand Dunes. J. For. Res 12, 350-357.

Vítková M, Tonika J, \& Müllerová J. 2015. Black locust: Successful invader of a wide range of soil conditions. Science of the Total Enviromental 505, 315-328.

Wang RZ. 2005. C3 and C4 photosynthetic pathways and life form types for native species from agro-forestry region, Northeastern China. Photosynthetica 43(4), 535-549.

Xu F, Guo W, Wang R, Xu W, Du N, \& Wang Y. 2009. Leaf movement and photosynthetic plasticity of black locust (Robinia pseudoacacia) alleviate stress under different light and water conditions. Acta Physiol Plant. 31, 553-563.

Yang Y, Tang M, Sulpice R, Chen H, Tian S \& Ban Y. 2014. Arbuscular mycorrhizal fungi alter fractal dimension characteristics of Robinia pseudoacacia L. seedlings through regulating plant growth, leaf water status, photosynthesis, and nutrient concentration under drought stress. $J$. Plant growth Regul. 33(3), 612-625.

Zeid IM \& Shedeed ZA. 2006. Response of alfafa to putrescine treatment under drought stress. Biologia Plantarum 50(4), 635-640.

Zhu XC, Song FB, Liu SQ, Liu TD \& Zhou X. 2012. Arbuscular mycorrhizae improves photosynthesis and water status of Zea mays L. under drought stress. Plant Soil Environ. 58(4), 186-191. 